\title{
Orçamentos Participativos em Portugal Em busca de uma democracia de maior proximidade ou de uma racionalidade funcional?
}

\author{
Nelson Dias $^{1}$ e Giovanni Allegretti ${ }^{2}$
}

\begin{abstract}
Resumo: Os orçamentos participativos representam uma possível tendência de evolução da democracia nas sociedades modernas. Este novo experimentalismo democrático está hoje presente em todos os continentes, com maior destaque para a América do Sul, Europa e África, assumindo configurações e sentidos locais muito diferenciados, até por vezes contraditórios. Em Portugal, o Orçamento Participativo tem ganho uma visibilidade crescente e trilhado um caminho de expansão bastante interessante e significativo. Tratando-se de uma realidade recente no nosso país, importa compreender as formas de inserção do OP no contexto político-administrativo local, os modelos de participação que incorpora, o desenho institucional que adquire, assim como os recortes organizacionais em que se enquadra. Neste artigo os autores procuram ainda reflectir sobre os limites, os desafios assim como as possíveis evoluções deste fenómeno em Portugal.
\end{abstract}

Palavras-chave: Orçamento Participativo, Democracia, Portugal.

“A democracia não é só o voto nas urnas. Na complexidade do mundo contemporâneo, a vida democrática descentra, dando vida a uma variedade de aç̧ões e instituições para além do sufrágio universal"

(Pierre Rosanvallon, La légitimité démocratique, Seuil, Paris, 2008)

\section{Introdução: desencanto e mal-estar da democracia}

Vinte anos depois da queda do muro de Berlim e do colapso dos regimes ligados ao bloco soviético, a maior parte do continente europeu está unido por instituições comuns, assentes na democracia representativa e no Estado de direito. Embora as diferenças entre o Ocidente e o Leste estejam longe de se considerarem completamente ultrapassadas, pela primeira vez na história está a delinear-se uma cultura democrática partilhada, onde os principais espaços públicos europeus tendem a debater, simultaneamente, os mesmos temas. Entre eles, tem sem dúvida o da recusa da política tal como está hoje a ser conduzida pelas elites do continente, do qual foi um claro sintoma a rejeição da Constituição europeia, ditada pelos referendos em França, na Holanda e na Irlanda. Se a dinâmica europeia parece fortemente paralisada, dividida entre concepções divergentes e ameaçada pelos retrocessos nacionais - e até mesmo nacionalistas - também em muitos dos países da União os sistemas políticos são confrontados com uma desilusão ou com uma crise de legitimidade. A democracia representativa tradicional já não parece susceptível de fazer face aos novos desafios e de mobilizar as energias e a confiança das populações. Se a abstenção aumenta um pouco por todo o lado (com evidências preocupantes nas áreas metropolitanas de países ocidentais como a França, a Inglaterra e Portugal) é porque a confiança dos cidadãos nas instituições e na classe política sofre um retrocesso, enquanto diminui quantitativamente o empenhamento nos partidos, e a militância nos sindicatos e em muitas outras estruturas de agregação social fica mais dis-

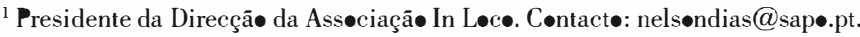

${ }^{2}$ Investigador do Centro de Estudos Sociais da Universidade de Coimbra. 
tante. Paralelamente, emerge uma falta de espaços onde as próprias instituições possam construir uma relação de diálogo permanente com os habitantes, e tornarem-se confiantes na capacidade dos cidadãos de não expressarem apenas desejos e intenções baseados no egoísmo e no individualismo social, mas numa visão solidária assente na identificação dos bens comuns e dos interesses colectivos. Uma situação deste tipo, baseada na ausência de confiança mútua entre administradores e administrados torna-se um factor social e politicamente perigoso, na medida em que desencadeia um círculo vicioso que extremiza o distanciamento progressivo entre as duas esferas, afastando cada vez mais os habitantes das instituições (num progressivo retrocesso fechado nas esfera individuais ou familiares) e fazendo com que estas últimas ponham cada dia mais a capacidade decisória dos cidadãos "sob tutela" porque acham que eles não conseguem organizar saberes e elaborar pareceres para além da esfera restrita das demandas subjectivas e de perspectivas pouco abrangentes e de curto prazo. Trata-se da situação que Boaventura de Sousa Santos descreve como a "dupla patologia das democracias liberais" (2008), a qual - por um lado - é uma patologia da representação, na medida em que os cidadãos estão cada vez mais distantes da vida política e dos eleitos (que por vezes nem os conhecem) e - por outro lado - representa uma patologia da participação, que se prende com uma ideia cada vez mais comum de que "não vale a pena participar", pois os cidadãos "sentem-se demasiado pequenos" para enfrentar os grandes interesses e as dinâmicas políticas e económicas que dominam a sociedade, e não confiam nas promessas dos representantes institucionais. Rosanvallon (2008) bem identifica o elo que une as duas patologias num único fenómeno, ou seja a questão da recíproca "confiança" entre sociedade instituinte e sociedade instituída, sendo que a "confiança" é ao mesmo tempo o motor que permite à democracia representativa de tomar forma - através da delegação de poder - mas também constitui a base para qualquer empenho do indivíduo na participação. De facto, qualquer processo voluntário de envolvimento político só pode tomar forma se os cidadãos tiverem confiança na capacidade do percurso participativo de "incidir" na transformação da realidade, dado que os balanços empíricos revelam que a participação (Allegretti, 2007) não é uma variável independente, mas sim uma variável estritamente dependente dos resultados concretos que é capaz de produzir.

Numa tal perspectiva, o facto de - a partir dos anos 90 - também no Velho Continente se tenha multiplicado o número dos processos participativos, especialmente ao nível da vida política local de vários países, pode ser entendido como um sinal positivo de capacidade auto-regenerativa da acção governativa e do exercício político. Esta evolução não parece conjuntural e marca, provavelmente, uma tendência a longo prazo (Sintomer/Allegretti, 2009). As razões não são fáceis de decifrar. Elas provavelmente tem a ver com profundas transformações socioculturais que incentivam uma procura de democratização do sistema político, incapaz de "ficar imune ao desenvolvimento maciço da educação, à crise da maior parte das estruturas dominadoras (da família patriarcal à escola, dos partidos aos laboratórios de investigação), à instauração de relatórios mais igualitários entre os sexos, ao maior número de discussões públicas sobre a ciência e a técnica, à emergência de um modelo de informação mais assente numa rede do que numa integração vertical, à relativização do modelo taylorista ou ao desmoronamento dos modelos económicos assentes na planificação autoritária" (id.).

$\mathrm{O}$ aspecto interessante é que este tipo de evolução parece estar em profundo desacordo com a profissionalização e a desmobilização no mundo político, que têm vindo a aumentar, e com tendências autoritárias que contrastam com as expectativas sociais de um horizonte mais democrático: por exemplo, dentro do espaço da empresa (que hoje parece mais fechado à co-gestão do que nos anos 80) e na procura de segurança que vai crescendo, determinando sucessos significativos em favor da extrema-direita e das correntes xenófobas. Estes contra-fluxos parecem aumentar perante a persistência de uma "questão social", que origina a insegurança e a precariedade no trabalho assalariado, impotência aparente da política diante da globalização económica, inadequação das instituições existentes para enfrentar novos desafios, perda dos referentes identitários tradicionais, sem que novos se imponham de maneira clara, efeitos ambivalentes que voltam a pôr em causa a crença "no progresso" (Sintomer/Allegretti, 2009).

A convivência de tendências equívocas e contraditórias na transformação das tradicionais relações sociais e políticas de cariz autoritário e 
paternalista prende-se com uma longa crise que - desde as mobilizações que se seguiram ao Maio de 1968 até a emergência das problemáticas de auto-gestão ligadas aos novos movimentos sociais altermundialistas - introduziu a palavra de ordem "fazer a política doutra maneira".

O desencanto democrático ao mesmo tempo favoreceu o desinteresse relativamente à coisa pública, e novas formas de implicação dos cidadãos na vida colectiva, aquelas que Rosanvallon (2008) designou com o nome colectivo de "contrademocracia”, um termo forte e voluntariamente ambíguo que reúne o conjunto de múltiplas actividades que não visam associar o cidadão ao exercício do poder, mas "organizar o seu controlo sobre quem governa". Sobretudo através da vigilância cívica, da atitude acusatória que (saída do âmbito judiciário) "disseminou-se com o tempo por toda a sociedade, tornando-se um património colectivo" e da "soberania negativa", ou seja, dum confronto com o poder que recusa algumas escolhas governativas e o descrédito da acção burocrática, refutando que a democracia esteja apenas assente no consenso silencioso, mas convencido que a divergência desempenha "um papel essencial na actividade democrática" (Rosanvallon, 2009).

Conforme já indicado, entre as mudanças recentemente estimuladas pelo crescimento das formas de "contrademocracia", tem sido relevante a dinâmica de expansão de arenas de discussão pública que têm tentado representar um novo "ponto de encontro" entre acção cidadã e actuação institucional. Na Europa, tais experimentações tomaram forma frequentemente com base em propostas institucionais, visando auto-reformas das esferas da política representativa, embora várias delas se tenham inspirado em experiências nascidas em contextos diferentes (e nomeadamente no Sul do planeta) a partir de mobilizações autorganizadas nos tecidos sociais. Entre elas, assumiram importância e visibilidade crescente os assim chamados "orçamentos participativos" (OP) que na última década - no continente europeu - passaram de poucas unidades até mais de 200 casos.

É sobre estes dispositivos que o presente artigo se vai debruçar, como prisma privilegiado para ler um aspecto inovador duma sociedade europeia percorrida por movimentos contraditórios, e dividida entre as derivações autoritárias, as lógicas tecnocráticas e as dinâmicas participativas. Nome- adamente, a recente experiência portuguesa em rápida ampliação será utilizada como instrumento para ler os desafios, os limites e as potencialidades ainda inexprimidas desta mudança de paradigma. As reflexões apoiam-se ao trabalho do projecto "Orçamento Participativo: mais participação melhor democracia" financiado pela Iniciativa Comunitária EQUAL, que os dois autores coordenaram, e no qual desenvolveram em Junho de 2008 um inquérito nacional sobre os OP portugueses ao qual responderam 19 das autarquias solicitadas.

\section{Definir e analisar os orçamentos participativos no quadro europeu}

Os orçamentos participativos (OP) não constituem "nem uma experiência marginal, que estaria completamente em contracorrente, nem uma vanguarda, que representaria a guarda avançada de uma evolução geral" do panorama político europeu (Sintomer/Allegretti, 2009). Eles apenas representam uma possível tendência de desenvolvimento da democracia, mas inscrevem-se "num movimento de fundo, num imperativo deliberativo e participativo que apoia a afirmação de um novo espírito dos serviços públicos e que se ancora, de maneira crescente, na prática" (id.). Embora a questão da articulação entre os mecanismos participativos e os movimentos sociais, decisiva para o futuro desta dinâmica, continue completamente em aberto, os orçamentos participativos representam um dispositivo mais interessante e paradigmático do que outros, porque tratam um tema complexo, que põe em estreito relacionamento o mundo da decisão política, a organização técnica das instituições públicas, e a esfera da autonomia organizativa social. Além disto, eles não constituem um modelo "único" e monolítico, mas configuram uma pluralidade de famílias de processos de participação, que mostra como esta tendência pode revestir-se de sentidos diferentes, e fazer referência a horizontes contraditórios.

Mas como pode ser definido um orçamento participativo? A existência de muitas experiências diferentes, incluindo várias assim autodenominadas por razões de utilitarismo político (ou raramente de ingenuidade), torna difícil oferecer uma definição "normativa". Dado que a história das ciências ensina-nos que as noções e as categorias com as quais os humanos apreendem o mundo, são cons- 
truídas socialmente, e que as manipuladas pelos investigadores não escapam à regra [Desrosières, 2000], uma definição objectiva ou essencial, que visasse fixar cientificamente o que é "realmente" um orçamento participativo, não parece legítima. Podem apenas alegar mais coerência, reflexividade e profundidade teórica do que as categorias empregadas no quotidiano pelos intervenientes no terreno, e reivindicar um valor heurístico naquilo que permite esclarecer melhor os fenómenos sociais, e é aí que têm uma força específica de conhecimento. É portanto preferível adoptar uma solução de orientação weberiana, propondo uma definição essencialmente metodológica dos orçamentos participativos europeus, conforme imaginado por Sintomer/Herzberg/Röcke (2005) na primeira rigorosa comparação das experiências europeias realizada com base numa homogeneidade de alguns critérios mínimos. Se Max Weber definia o Estado pelo seu meio específico (o monopólio da violência física legítima) e rejeitava uma definição apoiada sobre os objectivos prosseguidos pelo Estado, argumentando que estes eram demasiado diversificados e pouco específicos para fornecer um critério coerente e unívoco, da mesma maneira a nossa definição para orçamentos participativos apenas limitar-se-ia a alguns critérios, com o objectivo heurístico de difundir uma definição suficientemente alargada, para poder analisar um número significativo de experiências (nomeadamente entre as que se afirmam como orçamentos participativos), mas bastante restrito para impedir a entrada de qualquer processo participativo, diluindo a originalidade do objecto estudado. Obviamente, adoptando a perspectiva das experiências portuguesas, poderíamos ter, legitimamente, adoptado outros critérios mais específicos ou restritivos ligados à homogeneidade do contexto social e político nacional; mas o risco seria de perder a comparação com outros contextos e também uma perspectiva de "evolução" possível que - para os OP's - representa uma componente essencial do mesmo dispositivo.

Nesta óptica, poderia ser útil adoptar a perspectiva epistemológica do "pensée par cas" [Passeron/Revel, 2005], que parte dos estudos monográficos como trampolim para um trabalho de generalização da explicação que continua a construir-se, em parte, sobre o modelo da jurisprudência no domínio do direito: ou seja, o estudo de cada caso, por pouco interessante que seja, põe em destaque alguns traços singulares que não se reduzem às generalidades anteriormente existentes e faz mover as linhas explicativas globais. Uma tal perspectiva corta com a análise hermenêutica, que visa encontrar a verdade de um fenómeno a partir de uma reflexão interpretativa sobre o sentido que lhe conferem os intervenientes, mas também opõe-se a uma acção popperiana fixada sobre a "refutabilidade" das explicações (menorizando a singularidade de leis "monótonas" e desejando obter generalidades, que poderiam ser aplicadas, mecanicamente, no estudo de casos futuros). Ela requer sem dúvida um vaivém contínuo entre a investigação empírica, a teoria sociológica e a teoria política, para poder caracterizar metodológica e especificamente os orçamentos participativos, perante outros dispositivos de diálogo social.

Com as cautelas acima referidas, poder-se-ia definir o orçamento participativo utilizando os termos do manual do UN-HABITAT organizado por Y. Cabannes (2009), ou seja como "um mecanismo (ou processo) através do qual a população decide, ou contribui, para a tomada de decisão sobre o destino de uma parte, ou de todos os recursos públicos disponíveis". Ou - ainda - com as palavras de U. de Souza, o orçamento participativo poder-se-ia designar como "um processo democrático directo, voluntário e universal" que "combina a democracia directa com a democracia representativa" e onde "as pessoas podem discutir e decidir sobre orçamentos e políticas públicas" (Genro/de Souza, 1997).

A data de nascimento dos primeiros OP's estruturados está fixada na literatura em 1989 (apesar de experimentações anteriores, pequenas ou parciais), quando apareceu nalgumas cidades brasileiras - a mais conhecida das quais tornou-se Porto Alegre (cfr. Santos, 2003) - enquanto fora do Brasil começou a tomar forma a partir de 1990. Conforme Cabannes reconhece (2004) poderiam ser identificadas três grandes fases de expansão: a primeira (1989-1997) caracterizada pela experimentação em um pequeno número de cidades-piloto; a segunda (1997-2000) marcada pela consolidação no território do Brasil, em que mais de 130 cidades adoptaram o orçamento participativo; e a terceira (de 2000 em diante) caracterizada pela expansão e diversificação fora do Brasil, por exemplo na Europa e em particular em municípios da Espanha, da Itália, da Alemanha, da Inglaterra e mais recentemente de Portugal, da Polónia e da Suécia. 
Para permitir a cidadãos não eleitos participar na concepção ou na distribuição das finanças públicas, o OP necessita de um forte empenho comunicativo, capaz de associar análises técnicas articuladas e linguagens simplificadas, assim como narrativas e números, para valorizar o conteúdo político de documentos e procedimentos que ao longo do tempo foram artificialmente tecnicizados, tornando-se apenas compreensíveis para uma elite altamente especializada (Allegretti, 2003, 2005).

No caso europeu - conforme sugerido pelo inquérito comparativo "Participatory Budgets in a European Comparative Approach. Perspectives and Chances of the Cooperative State at the Municipal Level in Germany and Europe" (Sintomer/Allegretti, 2009), seria necessário acrescentar à definição geral cinco critérios para distinguir os orçamentos participativos de outros dispositivos afins:

(1) $\mathrm{O}$ facto de discutir explicitamente a dimensão orçamental e/ou financeira. Sendo que qualquer acção participativa implica uma dimensão financeira (na medida em que as decisões daí procedentes, ou que influencia, necessitam de meios humanos e monetários) a especificidade dos orçamentos participativos é abordar de frente esta componente, fazendo uma dimensão essencial do orçamento, e pondo em destaque que se trata de gerir recursos limitados.

(2) O facto de um orçamento participativo se referir à cidade (ou qualquer freguesia ou outro organismo descentralizado, que compreenda uma assembleia eleita e que tenha algum poder sobre a administração). De facto, a escala do bairro não é, por si só, suficiente. Este critério é necessário para diferenciar os orçamentos participativos das estruturas de conselhos de bairro, fundos de bairro ou fundos comunitários (dos quais existem centenas de exemplos na Europa), os quais dificultam uma compreensão da complexidade e da abrangência territorial por parte dos participantes, sendo que limitam o seu alcance a micro-áreas.

(3) O procedimento deve repetir-se no tempo: em certos países, adopta-se, frequentemente, o recurso a reuniões ou referendos pontuais sobre temas orçamentais, mas estas iniciativas não constituem orçamentos participativos na medida em que não enfrentam a complexidade de decidir através do confronto e do conflito entre opiniões e argumentações, que necessitam de ampliar os prazos e espaços de diálogo para se compor numa visão colectiva.

(4) O processo deve incluir certas formas de deliberação pública em assembleias ou fóruns específicos. Assim, uma sondagem sobre as finanças municipais não é um orçamento participativo, não passando de um conselho da comunidade (ou de uma comissão extra-municipal tradicional) aberto ao público por ocasião de um debate orçamental. A ideia de confrontar argumentações e - possivelmente - estabelecer prioridades e hierarquias de urgências a ser financiadas com os recursos disponibilizados para o processo, constitui uma especificidade dos OP's.

(5) Os responsáveis da acção participativa devem dar contas dos seus resultados, nem que seja sob a forma de acta, da sequência que tomaram as discussões (noção de accountability). Não seriam portanto orçamentos participativos aqueles, cujos resultados das discussões não são objecto de uma certa publicidade, e não promovem a monitorização e avaliação das acções no tempo.

Os instrumentos assim definidos inscrevem-se numa chamada formal à participação, que Blondiaux e Sintomer (2002) têm definido como "imperativo deliberativo". A difusão extremamente rápida que os OP's conheceram no mundo e o eco político que suscitaram, especialmente após os Fórum Sociais Mundiais do 2001 e 2002, tornaram-nos objecto de interesse para sujeitos muitos diferentes, desde organizações radicais do movimento altermundialista até o Banco Mundial, várias agências da ONU, partidos de esquerda ou de extrema-esquerda e fundações interpartidárias. À primeira vista, as razões do sucesso dos orçamentos participativos são numerosas quanto às perspectivas de análise que foram utilizadas para louvar a sua criatividade. Em primeiro lugar, tomando como ponto de partida as experiências latino-americanas, os OP's parecem ser uma via para reinventar a política e redistribuir os recursos em benefício dos mais desfavorecidos. Em segundo lugar, o dinheiro é, como se sabe, o motor da guerra, e o orçamento está no cerne do funcionamento dos serviços públicos, tendo assim um forte valor prático e também simbólico. A participação dos cidadãos na sua resolução só seria possível em determinado grau, o que constitui, por conseguinte, um desafio emblemático, por maioria de razão, em período de "vacas magras" (cortes às finanças locais, crise económica internacional, 
etc.). Em terceiro lugar, este instrumento pode, potencialmente, permitir ultrapassar o bairrismo e os fenómenos NIMBY, através de uma leitura mais articulada e abrangente dos problemas sociais e territoriais, não concentrando a discussão e o debate sobre micro-áreas, embora muitas vezes acabe por tomar medidas de porte micro-local.

Os orçamentos participativos parecem poder contribuir, de maneira específica, para a justiça social e a modernização dos serviços públicos, induzindo os cidadãos a comparar o seu destino com o dos seus iguais, a interessarem-se pelas opções políticas de fundo e a intervirem no centro da máquina administrativa. Estas estruturas parecem susceptíveis de sustentar uma modernização em todos os sentidos, o que é importante num período em que se põe em causa modelos meramente de gestão, como os que propunham, inicialmente, as organizações internacionais. Podem revelar-se atractivos, não só para consultores internacionais preocupados com o facto de que o dinheiro distribuído seja utilizado eficazmente, mas também para militantes que proclamam "que outro mundo é possível", e esta convergência inesperada de intervenientes também diferentes é, indubitavelmente, uma das chaves do seu sucesso (Sintomer/Allegretti, 2009).

Numa tal perspectiva é razoável que surja uma dúvida, ou seja, se um princípio que é o fruto de expectativas tão diversas, não estará votado a naufragar na confusão. De facto, a multiplicidade dos contextos em que foram experimentados orçamentos participativos e as diferentes formas tomadas poderiam tornar muito superficial a unidade deste fenómeno. O caso do desenvolvimento dos OP's na Europa oferece-nos - de todas as formas - a prova que as estreitas relações entre práticas e contextos frequentemente determinam convergências de objectivos e modelos procedimentais no interior de unidades orgânicas mais ou menos homogéneas ou afins. Tentaremos, portanto, nos parágrafos seguintes identificar alguns elementos característicos das experiências portugueses para entender um pouco mais as potencialidades desta inovação, que parece poder representar o símbolo de um "espírito novo" das instituições públicas (Bacqué/Rey/Sintomer, 2005) ou o sinal tímido de uma "democratização da democracia", obtida graças a formas mais flexíveis, mais colectivas e menos hierárquicas no que respeita a tomadas de decisão (Santos, 2003), mais do que apenas um lado contraditório da emergência de uma "democracia de opinião" (Manin, 1995), dominada pela demagogia, pelas manipulações mediáticas, pelas molas carismáticas e por uma despolitização de facto. Nesta óptica, o OP tem vindo a transformar-se num "Tema Maior" (Dias, 2008), capaz de influenciar a agenda programática de diferentes classes políticas, oferecer alternativas para contrariar a crise da democracia liberal e favorecer uma maior aproximação dos cidadãos e cidadãs à coisa pública.

\section{Portugal dentro de um desenvolvimento tardio mas exponencial}

As definições anteriormente oferecidas permitem fixar e avaliar, de forma inequívoca, o desenvolvimento dos orçamentos participativos no velho continente, cujos números são impressionantes, embora descrevam um fenómeno ainda minoritário no panorama das inovações municipais. Se, em 1999, os OP's europeus se contavam pelos dedos de uma mão, em 2002 as experiências excediam as duas dezenas; em 2005 os orçamentos participativos eram 55, e o movimento contínuo fez com que chegássemos a 2009 com quase 200, embora alguns processos tenham estagnado, demonstrando-se frágeis e voláteis face à relação com a vontade política que os sustenta, num quadro que não prevê obrigações formais de experimentar (como acontece em países latino-americanos como o Peru e a República Dominicana).

Esta expansão, a qual (tudo indica) vai prolongar-se nos próximos anos, é ainda mais notável, na medida em que se refere a cidades de dimensões muito diferentes. Enquanto que em 1999 só existia um concelho de mais de 100 mil habitantes com OP, já em 2002 estavam envolvidas quatro experiências, e 17 em 2005. Hoje as cidades europeias com OP e mais povoadas são Colónia - na Alemanha -, Sevilha - na Andaluzia - e algumas freguesias de Paris, Berlim, Roma e Londres. Lisboa é a primeira capital europeia a instaurar um processo participativo dirigido neste sentido, a partir de 2007, na totalidade do território municipal. Duas regiões, Poitou-Charentes e Latium, também iniciaram um processo que autodefiniram como tal, enquanto alguns departamentos e pelouros apoiam activamente as experiências de envolvimento dos habitantes na tomada de decisões económico-financeiras sobre o 
seu território. Longe de estar concentrado em um ou dois países, o fenómeno estende-se geograficamente. Em 2005, contam-se quinze experiências em Itália, catorze em Espanha, onze em França, dez na Alemanha, três na Grã-Bretanha, duas em Portugal e uma na Polónia. Depois, a Espanha e ainda a Itália cavaram a diferença, e Portugal hoje excede largamente a França. O fenómeno está, literalmente, a explodir na Grã-Bretanha ${ }^{3}$, na Suécia ${ }^{4}$. Na Albânia e em países da ex-Jugoslávia o Banco Mundial tem vindo a apoiar o "start-up" de experiências-piloto.

Até 2006, mais do que o tamanho, a situação socioeconómica, o contexto urbano ou o grau de legitimidade do sistema político (abstenções etc.) parece que foi sobretudo a ancoragem política à esquerda - e, mais ainda, a presença de uma coligação que incluísse os comunistas ou a esquerda alternativa - que parece ter promovido as experiências de orçamento participativo europeias. Perante a origem do orçamento, inventado no concelho radical de Porto Alegre, não é muito surpreendente o impacto que as primeiras experiências brasileiras tiveram no movimento altermundialista. Contudo, a atitude que a esquerda mantém, no que diz respeito à participação, está longe de ser unívoca, e existem numerosas correntes, das mais moderadas às mais radicais, que se inscrevem numa orientação resolutamente paternalista.

$\mathrm{O}$ facto de um número crescente de concelhos de esquerda, na Europa, ter-se interessado por uma experiência vinda do Sul parece bastante excepcional, ao ponto de ter levado autores a falar de "regresso das caravelas" (Allegretti/Herzberg, 2004). Uma notável diferenciação tem marcado especialmente a "via alemã" do orçamento participativo, politicamente muito original porque emergiu tendo como base de orientação a experiência neozelandesa de Christchurch (cfr. Plamper, 2000), cidade que ganhou um prémio de boa governança da Fundação Bertelsmann. Esta fonte de inspiração ajuda a explicar a adopção desse procedimento por um número cada vez mais significativo de concelhos de direita na Alemanha, país onde o OP assume como principal foco a ideia de uma modernização da Administração Local.
Este último exemplo ilumina a importância que a "história cruzada" e as "transferências" entre diferentes países e experiências (Werner/Zimmermann, 2004) têm marcado no desenvolvimento dos orçamentos participativos no âmbito europeu, juntando-se com a capacidade de articular factores estruturais e factores locais contingentes, especificidades nacionais e modelos transnacionais do tipo que Appadurai (1991) definiria "ideoscape", ou seja que circulam a nível planetário mas apenas se tornam realidade através de fenómenos de apropriação local. De facto, no caso dos orçamentos participativos, parece claro que os mecanismos de inovação institucional têm sido marcados, fortemente, pela dependência em relação ao passado, descrita, na literatura académica, com o nome de «dependência do caminho» (path-dependency): as vias seguidas no passado influenciam, em grande medida, os caminhos que se oferecem no presente, incluindo a criação de algo novo para o futuro.

$\mathrm{Na}$ Europa, de facto, os orçamentos participativos desenvolvem-se, frequentemente, com base em procedimentos participativos que existiam de antemão e dos quais integram elementos (Sintomer/ /Allegretti, 2009). E a relação deles com o passado pode existir (em forma de antítese) também quando a ênfase sobre a "novidade" (como no caso do procedimento importado de Porto Alegre) pretende sublinhar a verdadeira "ruptura" com as práticas já existentes. Neste âmbito faz sentido a metodologia weberiana proposta na pesquisa comparativa de Sintomer/Herzberg/Röcke (2005), que se centrou na elaboração de alguns ideais-tipo, que permitem situar a multiplicidade das experiências de orçamento participativo do Velho Continente numa espécie de mapa conceptual, o qual pretende ajudar o leitor a se orientar na análise das diferentes famílias de OP europeus, colocando-os em relação com outros modelos de governação e com os principais objectivos que marcaram a sua adopção nas diferentes experiências municipais ou de freguesia.

O caso dos orçamentos participativos portugueses emerge como muito interessante para a capacidade de explicar estas duas últimas perspectivas, juntando o peso da "path-dependency" (ou seja da relação com o próprio contexto) e as abordagens

\footnotetext{
${ }^{3}$ Com a definição de uma estratégia nacional que visa a implementação do OP em todos os poderes locais do país até 2012.

${ }^{4} \mathrm{O}$ processo de disseminação do OP tem contado com o apoio da Associação de Municípios e Regiões do país, prevendo-se uma forte expansão do fenómeno nos próximos anos.
} 
que marcaram as primeiras experimentações-piloto de OP num modelo específico, que Sintomer/Herzberg/Röcke (2005) e Sintomer/Allegretti (2009) chamam de "democracia de proximidade", o qual encontra afinidades com as prevalências que marcam também a abordagem escolhida por países como a França e a Bélgica.

De facto, desde o início de 2002, o poder local em Portugal não ficou imune a esta dinâmica internacional, acabando por ser hoje um dos países da Europa que maior interesse vem despertando sobre o tema e no qual existe uma das proporções mais elevadas de "autarquias experimentadoras", no total geral daquelas que compõem o país. De 2002 à actualidade são conhecidas 25 experiências de OP em Portugal, das quais 21 promovidas por Municípios e 4 por Freguesias, tal como ilustrado no mapa seguinte. a estas novas formas de experimentalismo democrático olhando para ela com um cunho cada dia menos "ideológico" e mais atento a novas forma de experimentalismo na governação territorial.

De facto, se numa fase inicial o OP emergiu em Portugal com uma "ideia de esquerda", com especial destaque para os poderes locais governados pela Coligação Democrática Unitária (CDU), hoje é cada vez mais evidente a tendência para a emergência do OP em territórios liderados pelo Partido Socialista (PS) ou pelo Partido Social-Democrata (PSD). Começam mesmo a surgir as primeiras manifestações de vontade de implementação do OP em municípios governados pela coligação formada pelo PSD e pelo Partido Popular (CDS-PP).

Do conhecimento detido de momento, é expectável uma ampliação das experiências de $\mathrm{OP}$

\section{Figura 1}

Orçamento Participativo em Portugal (2008)
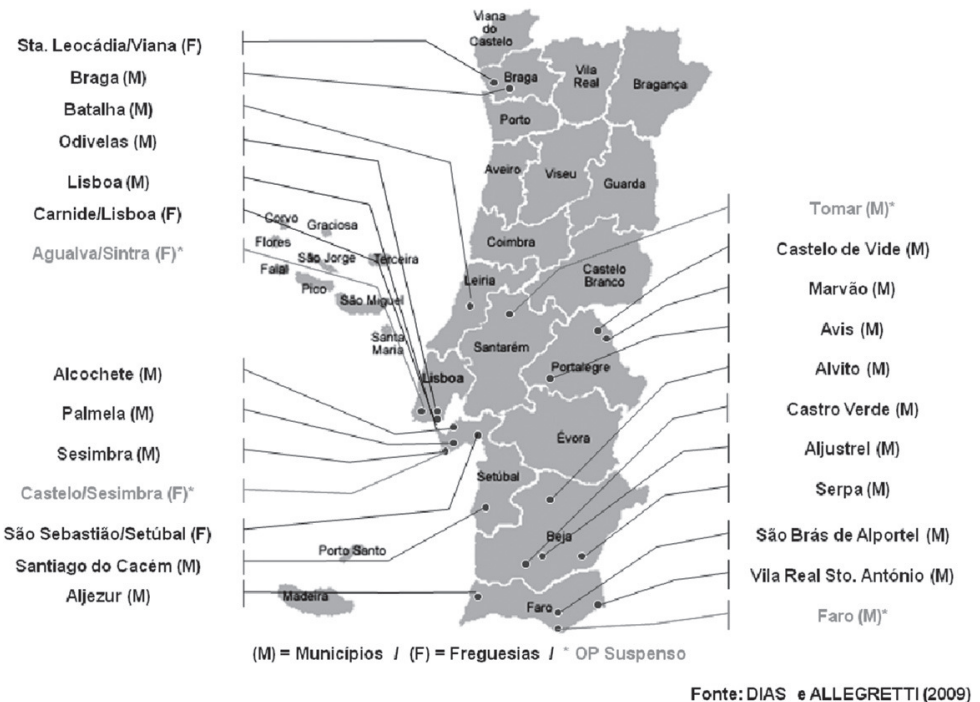

Um simples olhar sobre este mapa deixa perceber facilmente a tendência sulista da maioria das experiências de OP em Portugal. Esta realidade não é alheia à tradicional divisão política do país, segundo a qual no Norte existe uma presença mais dominadora das forças do Centro-Direita, enquanto que o Sul se posiciona maioritariamente ao Centro-Esquerda. No entanto, uma análise mais pormenorizada e cronológica da evolução dos $\mathrm{OP}$ em Portugal permite afirmar que as diferentes forças partidárias, incluindo os movimentos independentes que governam algumas autarquias, se estão a abrir em territórios governados localmente pelo PS e pelo PSD, partidos que, aliás, disputam a maioria dos poderes locais no país.

Em termos práticos, na actualidade, das 25 autarquias indicadas no mapa anterior, $44 \%$ são governadas pela CDU, 24\% pelo PS, o mesmo valor para o PSD, enquanto que $8 \%$ são governadas por Movimentos Independentes.

Outro dos elemento que permite pensar que o OP não se acantonará numa qualquer área política tem que ver com o facto de não existirem de momento evidências que permitam distinguir 
formas de organização e de implementação do OP que dependem especificamente da força partidária que o promove. Aliás, as características dos $\mathrm{OP}$ em Portugal parecem depender muito mais das variáveis estruturais relacionadas com o legado institucional e sociopolítico conforme veremos no próximo ponto.

\section{O peso do contexto}

Alguns elementos do contexto sociopolítico e institucional português tiveram um peso não secundário na forma assumida pela maioria dos orçamentos participativos desenvolvidos até hoje em Portugal.

Vale portanto a pena lembrar que a estrutura administrativa prevista pela Constituição da República Portuguesa de 1976 e assente na existência das designadas "autarquias locais" (art. 235. ${ }^{\circ}$ ), é constituída por 308 municípios, que se subdividem em 4259 "freguesias", organismos de descentralização político-administrativa (que existem em poucos outros países da Europa, como em Inglaterra, em Itália e nas maiores capitais da França) os quais - no caso português - derivam da antiga articulação territorial das paróquias. Quanto à formação de regiões administrativas (prevista na Constituição), o processo de regionalização - depois de uma consulta às Assembleias Municipais - foi travado pelo referendo de Novembro de 1998, o qual não aprovou o mapa de oito regiões oficializado pelo Decreto-Lei 18/98. Actualmente, apenas nas ilhas estão previstas duas verdadeiras Regiões Administrativas Autónomas (Madeira e Açores) que compreendem várias freguesias e municípios ${ }^{5}$.

Um elemento raro no panorama europeu, mas convergente com alguns casos da área escandinava, diz respeito à presença de membros eleitos dos partidos de oposição não apenas nas assembleias mas também nas Câmaras e nas Juntas; um legado que complica a vida política do Executivo, mas é compreensível na situação pós-revolução em que a regra foi concebida, tendo como objectivo valorizar todas as forças vivas da sociedade. Outro elemento que pode complicar a introdução de inovações nos mecanismos de governação relaciona-se com o sistema dualista em que as eleições dos organismos executivos e deliberativos são separadas mas simultâneas, salvo no caso de ocorrência de eleição intercalar. Esta "separação" (que não acontece em outros países (como França e Espanha, por exemplo) torna Portugal parecido com o Brasil, onde muitas vezes os dispositivos participativos (especialmente se forem activados pelo o Executivo) são mal percebidos pelos membros das assembleias porque considerados como "perigos" à integridade das suas competências e das suas capacidades decisórias.

Um outro elemento que diferencia Portugal também de outros países onde existem as freguesias (como Itália, Inglaterra o as grandes metrópoles da França) é o facto que na Assembleia Municipal apenas uma parte dos membros ser directamente eleita, devendo estes ser em número superior ao dos presidentes de junta de freguesia, que também a integram como "membros de direito".

Falando do nível das freguesias, merece ser realçado que o funcionamento delas é garantido por uma percentagem do Orçamento Nacional, transferida directamente para elas, enquanto que as suas competências mínimas são relativas a tarefas de desconcentração administrativa e de gestão dos processos eleitorais. As outras responsabilidades sobre serviços e espaços públicos podem ser acrescentadas com base em acordos específicos entre cada freguesia e a respectiva Câmara Municipal. Sendo o tamanho e a estrutura organizativa/funcional das freguesias muito diferentes (de poucas centenas até 65000 habitantes) a distribuição das competências e das responsabilidade tem necessariamente que ser de "geometria variável", o que diferencia Portugal de outros países europeus como a Itália, onde as freguesias (circoscrizioni) de um mesmo concelho tem todas as mesmas competências e dimensões não tão díspares.

De um ponto de vista da cultura administrativa, vale a pena realçar que até hoje a tradição política portuguesa assentou numa forte continuidade das pessoas e das "famílias políticas". Apenas 3 Presidentes de Câmaras dos país são eleitos como "independentes" fora do leque do partidos tradicionais e os dados do STAPE mostram como os cidadãos estrangeiros de muitos países, que desde 1996 tem direito ao voto activo e passivo

\footnotetext{
${ }^{5}$ Pelo contrário, em Portugal Continental o "mapa das cinco regiões" (Norte, Centro, Lisboa e Vale do Tejo, Alentejo e Algarve) corresponde apenas às cinco comissões de coordenação e desenvolvimento regional (CCDR).
} 
nas eleições autárquicas (unicidade que diferencia positivamente Portugal de muitos outros países da Europa), raramente têm entrado no mundo da política, situação que se deve às dificuldades práticas de aceder à uma política local não muito "acolhedora" ${ }^{\prime \prime}$. Desde 2005 que o mandato dos presidentes dos órgãos executivos das autarquias locais não pode ser renovado por mais de três vezes consecutivas. Esta medida - em vigor há mais tempo em outros países europeus - chegou a Portugal recentemente.

Existe em Portugal uma difusa consciência de que esta complexa arquitectura necessita de uma revisão a curto ou médio prazo. Entretanto, as propostas de reformas apresentadas no tempo nunca chegaram a ser verdadeiramente partilhadas e concertadas, não se baseando em estudos cuidadosos do funcionamento real das instituições autárquicas, mas sim em posições "ideológicas" normalmente apenas interessadas em reduzir os custos de gestão institucional e com pouco respeito pelo princípio de subsidiariedade.

Actualmente está em processo de análise, no Parlamento, uma reforma da Lei Eleitoral Autárquica (já aprovada pela Assembleia da República a 18 de Janeiro de 2008), a qual aponta para um modelo mais "presidencialista" dos poderes locais. Tal reforma prevê a eleição conjunta do presidente da câmara e da assembleia municipal, reforça o papel do presidente (livre de escolher os vereadores), reduzindo o carácter "colectivo" do executivo desenhado após a revolução de 1974, como garantia de um maior envolvimento de todas as forças políticas activas nos vários órgãos do concelho (incluindo mesmo a própria oposição). A nova Lei reforma igualmente as freguesias, propondo a sua redução. Embora não seja fácil imaginar em que medida uma transformação desta engenharia poderá facilitar a experimentação dos processos participativos e nomeadamente dos orçamentos participativos (porque muito vai depender do tipo de transformações a ser experimentadas e do método usado para construí-las) é certo que são pelo menos os âmbitos sobre os quais uma reforma poderá impactar significativamente.

O primeiro é o campo da articulação entre municípios e freguesias, que hoje em dia representa um espaço de tensão, dado que as freguesias tem dificuldade em realizar orçamentos participativos no seu nível de competência e de capacidade financeira (embora existam experiências interessantes e corajosas como as de Carnide, no concelho de Lisboa, e Santa Leocádia do Geraz do Lima, no concelho de Viana do Castelo), e ao mesmo tempo percebem como a escala certa para realizar diálogos directos com os cidadãos, tolerando mal as tentativas das Câmaras de experimentar um tal diálogo fora da mediação das freguesias. Por outro lado - na escala supramunicipal - a eventual criação de organismos electivos de nível superior aos municípios poderá impactar sobre os processos participativos, eventualmente trazendo o beneficio que já experimentaram regiões ou províncias da Itália (como Lazio e Toscana), da França, da Espanha e da Alemanha, onde tem-se experimentado linhas (ou até leis regionais) de apoio aos municípios para estimular a multiplicação de processos de participação.

Relativamente ao peso sobre a "path-dependency" das razões que, em Portugal, foram alimentando nestes últimos anos a experimentação de novas formas de participação cidadã na vida política local, convém tocar algumas delas, mesmo que de forma sucinta.

Em primeiro lugar, a tradição centralista do poder, com sequelas na cultura política e democrática de eleitos e eleitores. As primeiras eleições livres dos órgãos autárquicos datam de 1976, marcando, assim, a transição dos municípios de extensões auxiliares do Governo central para um modelo de Administração Local com maior autonomia e capacidade interventiva. Esta transição traduziu-se claramente numa maior democratização do poder local e num progressivo reforço da capacidade intervencionista do Estado em áreas como a criação de infra-estruturas e equipamentos colectivos, assim como na prestação de serviços à população.

Esta mudança no cenário político-administrativo português não foi todavia acompanhada de um processo real de participação dos cidadãos na coisa pública. Esses têm sido remetidos, em grande medida, para o papel de assistidos de um poder local que progressivamente se tem vindo a constituir como actor incontornável nas dinâmicas

\footnotetext{
${ }^{6} \mathrm{Cfr}$. Relatório do primeiro ano do projecto "Acesso formal dos imigrantes aos espaços políticos no contexto local: eleitores e eleitos nos municípios e freguesias portuguesas", coordenado pelo CES (Prof. Fernando Ruivo) e a SOCINOVA, e financiado pela Fundação para a Ciência e a Tecnologia (referência: IME/SDE/81870/2006)
} 
de desenvolvimento territorial. A implementação de processos participativos, como o OP, que implicam a adopção de novas formas de governação, mais democráticas e transparentes, representa assim uma clara mudança paradigmática - a passagem de um paradigma do assistencialismo público para o paradigma da co-responsabilização sobre a gestão da "coisa pública".

Esta transformação é muito pouco pacífica, na medida em que ela representa, por um lado, a adopção de uma nova cultura política por parte dos eleitos e dos cidadãos, e por outro lado (como já indicado), o repensar do desenho político-institucional que sustentou o processo de descentralização em Portugal.

Relativamente à cultura democrática é mais ou menos evidente que a classe política se considera normalmente legitimada pelos actos eleitorais, não reconhecendo a necessidade de despoletar processos de participação e de prestação de contas. No entanto, os próprios cidadãos deixaram de se interessar pela vida política, demitindo-se do envolvimento quer nas dinâmicas sociocomunitárias quer nas dinâmicas eleitorais (as últimas eleições e o referendo nacional sobre o aborto registaram um aumento preocupante das taxas de abstenção, especialmente na área da grande Lisboa).

Uma das lições que podemos retirar de países com democracia consolidadas, é que não basta instituir os princípios gerais da liberdade e dos direitos civis para a que a ordem democrática se estabeleça integralmente (Fedozzi, 2001). "Não é suficiente a realização de eleições verdadeiramente democráticas para garantir formas de governação próprias de uma democracia moderna, assentes na transparência da administração e na credibilização dos serviços públicos. Não basta assegurar a existência da institucionalidade democrática para desenvolver uma cultura política e democrática dos cidadãos" (Dias, 2006: 84).

Portugal enfrenta uma cultura de participação ainda pouco consolidada por parte dos seus movimentos associativos, em específico, e da população, em geral. A participação é normalmente resultado de processos pouco espontâneos, que no caso das pessoas individuais emerge sob a forma de respostas contestatárias e pontuais, frente a decisões pouco populares dos órgãos políticos. Por seu lado, os movimentos associativos encontram-se muito sectorializados e pouco ou nada organizados, dificultando actuações pró-activas em defesa de interesses globais. Não raras vezes, estes movimentos vivem acoplados a dinâmicas partidárias que lhes retiram capacidade interventiva, credibilidade e abrangência na acção.

Apesar disto - e embora em Portugal os Orçamentos Participativos não tenham sido solicitados por um amplo debate social (como aconteceu em algumas cidades da Itália) - é desde a sociedade civil organizada que tem emergido alguns dos actores que mais se especializaram na formação sobre $\mathrm{OP}$, contribuindo para a difusão do conhecimento científico do tema no país e para a construção de redes de intercâmbio com experiências de outros contextos nacionais ${ }^{7}$.

O débil desenvolvimento da cidadania portuguesa, com implicações directas na atitude da população em relação à política, é visível não apenas a nível nacional mas também local. A descentralização do Estado, através da municipalização da administração pública, a que normalmente se associa também a expectativa de maior democratização da vida política, acabou frustrando algumas expectativas, sobretudo por duas razões: por um lado, porque o desenho institucional em que assentou o processo de descentralização não criou uma ruptura suficientemente expressiva com a tradição centralista do poder, e por outro lado, porque a arquitectura dos poderes locais em Portugal foi desenhada tendo por base modelos institucionais muito hierarquizados. Em última instância isto significa que o processo de descentralização e o desenho institucional das autarquias não foram concebidos tende por base preocupações com a participação da população.

Outro dos elementos que marca o contexto sociopolítico de emergência de novos processos de participação cidadã são os casos recentes de corrupção nas autarquias. Esses têm sido amplamente mediatizados por parte dos órgãos de comunicação social, muitas vezes sem fundamentos muito consolidados, e gerando uma certa diabolização dos pode-

\footnotetext{
${ }^{7}$ Especificamente os autores deste artigo pertencem a duas destas instituições: uma social (a Associação In Loco e uma académica (o Centro de Estudos Sociais da Universidade de Coimbra) que coordenaram o projecto nacional "Orçamento Participativo Portugal", apoiado pela Iniciativa Comunitária EQUAL, junto com 3 autarquias (Câmara de Palmela, Câmara de São Brás de Alportel e JF de Carnide) e o Centro de Estudos e Formação Autárquica (CEFA) que tem contribuído amplamente para a divulgação do OP junto de técnicos e políticos de câmaras e freguesias portuguesas.
} 
res locais (Santos, 2008). As situações de corrupção nas autarquias emergem normalmente associadas a ilegalidades no sector do urbanismo, como os licenciamentos de construção e alterações ao uso dos solos, a que se agregam os casos de financiamento ilícito das máquinas partidárias e também de enriquecimento e favores pessoais. Estas situações reforçam a actual crise de representatividade dos órgãos políticos de que fala Alain Touraine (1994), somando-se à desilusão gerada nos cidadãos pelo hábito das estruturas autárquicas portuguesas de construir orçamentos previsionais normalmente pouco realísticos, demasiadamente incrementais e financeiramente supradimensionados, que raramente conseguem ser executados conforme as promessas (Baleiras, 2004).

Outro dos elementos a ter em conta nesta análise é a crescente "assimetria" que está a consolidar-se no âmbito da transferência de competências institucionais: do Governo para os municípios e dos municípios para as freguesias. A delegação de competências tem sido feita sem o correspondente acompanhamento financeiro, causando dificuldades óbvias ao poder local na criação de respostas adequadas às demandas da população. As autarquias, em especial as Câmaras Municipais, têm sido chamadas a intervir em áreas nas quais não era habitual, umas vezes por via da descentralização de competências, outras porque a própria população assim o "exige". As áreas da educação, acção social, cultura, desporto e actividades económicas são disso exemplo. Não podendo descurar as questões relativas às acessibilidades, ao saneamento básico e aos espaços públicos, as autarquias enfrentam hoje estes novos e renovados desafios, sendo obrigadas a pensar intervenções mais integradas e integradoras, e por vezes mais imateriais do que materiais. A falta de "certeza" claramente tem o risco de frustrar os participantes nos processos participativos (nomeadamente os que têm objectivos de médio-longo prazo como as Agendas XXI e as discussões sobre os Planos de Urbanismo), especialmente quando estes acontecem em âmbitos dotados de poucas competências e recursos próprios, como as freguesias - sobretudo as mais pequenas. Tudo isto perante um quadro de previsível e progressiva perda da capacidade financeira das autarquias, requer obviamente um exercício governativo de permanente aliança com entidades privadas, com e sem fins lucrativos, que permita ampliar a capacidade de acção e a captação de recursos.

A previsível renovação nos quadros políticos das autarquias, devida à nova lei eleitoral que impõe uma limitação de mandatos aos governantes, ainda não é um fenómeno muito visível ao nível dos "cabeças de lista" dos diferentes partidos. De todas as formas torna-se mais ou menos evidente que nas eleições do Outono 2009 estes serão obrigados a antecipar processos de renovação interna dos seus quadros, eventualmente apoiados pelas respectivas juventudes partidárias. Será este um elemento decisivo para a emergência de novas gerações políticas, eventualmente mais propensas à inovação democrática e à consequente implementação de processos participativos como o OP? A resposta fica em aberto, embora existam sinais cada vez mais evidentes dessa possibilidade, como demonstra o facto da idade média dos autarcas que hoje experimentam o OP ser mais baixa do que a média nacional. Outro indicador de interesse é o facto da maioria das experiências de OP ter sido impulsionada por presidentes que encontram num primeiro mandato eleitoral, demonstrando uma vontade de construir um "marco pessoal" próprio na gestão da coisa pública.

\section{Características dos Orçamentos Participativos em Portugal}

Pode o quadro acima delineado ter influenciado algumas das características dos OP portugueses? Para tentar compreendê-lo vale a pena examinar alguns elementos estruturantes que aparecem como marcos comuns das experiências portugueses.

\section{a) Os modelos de participação}

A maioria das experiencias de Orçamento Participativo em Portugal é de carácter consultivo. Isto significa que se centram normalmente na discussão de problemas, necessidades e propostas apresentados pelos cidadãos, sem que isso implique um debate efectivo sobre os orçamentos nem uma fase de priorização das escolhas indicadas pelos habitantes para financiamento. Em alguns casos, como acontece em Palmela e São Brás de Alportel, o processo parte de uma proposta inicial de projectos 
elaborada pelos respectivos Executivos, podendo vir a ser introduzidas alterações por via dos contributos dados pelos cidadãos nas "arenas deliberativas", ou seja, nos diferentes espaços de discussão e entrega de sugestões (através de encontros cara-a-cara ou de inquéritos escritos ou via Web) abertos aos habitantes.

Apesar desta ser a tendência maioritária, começamos a assistir neste momento à emergência de uma segunda geração de OP em Portugal, apostada em implementar processos de tipo decisório, sobre uma componente previamente definida do orçamento. Esta segunda geração é actualmente protagonizada por experiências como a dos Municípios de Lisboa (onde em 2008 o orçamento decidido pelos participantes ultrapassou os 5 milhões de euros) e de Sesimbra, assim como pela Freguesia de Santa Leocádia do Geraz do Lima (concelho de Viana do Castelo), no norte do país.

À margem da carga educativa e formativa para a cidadania que este tipo de processos pode ter, assim como dos ganhos em termos de transparência democrática, os OP's promovidos por Juntas de Freguesia são perspectivados sobretudo enquanto ferramentas de participação que ajudam a reforçar o papel desse nível administrativo na mediação política com as respectivas Câmaras Municipais. As Juntas de Freguesia em Portugal têm uma capacidade de investimento quase nula, assim como um leque de competências muito limitado, a não ser que específicos acordos anuais com os municípios aos quais pertencem ampliem este papel, atribuindo novas competências de gestão de sectores de serviços e infra-estruturas locais. Estes elementos, entre outros, podem levar as Freguesias a visualizarem o OP como um instrumento de reforço dos seus argumentos na negociação com as respectivas Câmaras Municipais, para que essas contemplem nos seus orçamentos determinados investimentos para a freguesia em causa.

Todas as experiências portugueses privilegiam a participação das pessoas em nome individual, embora algumas (como Braga, uma das maiores cidades com liderança socialista no Norte do país) permitam também sistemas de representação através de colectividades e associações locais. Este é um aspecto importante, na medida em que se conhece a situação de excessiva dependência do tecido associativo de base local dos apoios financeiros e logísticos prestados pelas autarquias, assim como alguma intromissão e influência das estruturas partidárias no seio das associações. Deste ponto de vista, os OP simbolizam parcialmente a ideia do retorno do actor individual, muito abandonada pela lógica dos sistemas democráticos representativos, no âmbito dos quais a relevância social e política é normalmente atribuída aos actores colectivos. A perspectiva desta pequena "revolução" é principalmente a de partir do indivíduo, usando como "motor" as suas necessidades específicas, para garantir a presença num espaço público onde se possam negociar visões mais colectivas e identificar "bens comuns".

Na perspectiva de analisar o modelo organizacional que tem sido privilegiado em Portugal, tem que se realçar que o enfoque assumido no país é tendencialmente de base "territorial". Isto significa que se privilegiam as dinâmicas de participação descentralizadas que permitem a incorporação nos debates das diferentes dimensões da vida local e microlocal. Referimo-nos concretamente à possibilidade de discutir no âmbito dos processos as diferentes áreas de interesse da vida das pessoas, como por exemplo, educação, saúde, acessibilidades, ambiente, cultura, desporto, urbanismo, economia, entre muitos outros. Este enfoque tende a valorizar as diferenças territoriais e as assimetrias intramunicipais como, por exemplo, a necessidade de compreender os problemas específicos das áreas urbanas ou rurais, dos bairros sociais mais degradados ou das áreas centrais patrimonialmente mais valorizadas, etc. Por outro lado, a adopção deste enfoque não é alheio ao facto dos Municípios em Portugal terem vindo a assumir progressivamente competências em quase todas as áreas, desde a criação de infra-estruturas de base até ao desenvolvimento da economia local. O facto deste enfoque ter por vezes limites de perspectiva, que não alcançam uma discussão sobre "escolhas estratégicas" para o território interessado, justifica parcialmente a inserção dos $\mathrm{OP}$ portugueses na categoria dos instrumentos de "democracia de proximidade" (Allegretti/Sintomer, 2009) dentro de uma leitura comparada das diferentes famílias de OP europeus.

A par desta tendência, começamos também a verificar a emergência das primeiras iniciativas cujo enfoque é sobretudo "actorial", ou seja, direccionado para determinados actores ou grupos sociais, como é acontece com as crianças e os jovens. 
É o caso de São Brás de Alportel que em 2007 implementou a primeira experiência de Orçamento Participativo Crianças e Jovens (OPCJ), envolvendo alunos das duas principais escolas do Município, numa parceria territorial que envolve o Município, a Associação In Loco e as próprias escolas (Dias, 2008). Pouco depois tiveram também início as experiências da Freguesia de Carnide, em Lisboa, envolvendo as crianças do $1 .^{\circ}$ ciclo de ensino, com idades entre os 6 e os 10 anos, assim como de Braga. Estas experiências assumem um papel importante ao constituírem-se como uma instância de socialização e de formação sobre o tema da democracia e da cidadania, sobretudo, num cenário de quase total ausência de instituições de sociabilidade que assumam claramente esta função. Ajudam também a dar substância a um panorama de iniciativas pseudo-participativas fragmentadas que em Portugal tem tido a ambição de trabalhar consensualmente alguns temas de interesse das comunidades escolares, e que encontram nas "Cartas" e nos "Conselhos" de Educação um instrumento - muitas vezes fraco - de desenvolvimento do diálogo social. Tomando em conta a recente evolução normativa (início de 2009) dos Conselhos da Juventude em Portugal, é possível imaginar para um futuro próximo alguns desenvolvimentos interessantes e eventuais articulações entre estes dois dispositivos "híbridos", envolvendo os jovens nas decisões territoriais.

\section{b) Desenho institucional}

A esmagadora maioria dos processos de $\mathrm{OP}$ em Portugal corresponde a um conjunto de reuniões entre os executivos e os cidadãos que normalmente têm lugar no último trimestre de cada ano. Esta periodicidade (que torna muito curto um ciclo que nos outros países europeus às vezes abrange $7 \mathrm{ou}$ 8 meses) deve-se essencialmente a quatro ordens de razão:

1) o carácter consultivo dos processos, o que não implica arquitecturas e desenhos institucionais muito complexos, nem a antecipação dos debates públicos, com vista à concertação e votação por parte dos cidadãos;

2) este é o período de ano em que os executivos se sentem mais confiantes para poderem "enfrentar" os munícipes. Isto deve-se ao facto de neste momento conseguirem ter uma previsão orçamental mais realista para o próximo ano, assim como um mais elevado nível de execução orçamental referente ao ano em curso;

3 ) as características de certa forma marginais que o $\mathrm{OP}$ assume dentro das prioridades autárquicas e do funcionamento da própria administração;

4) o baixo impacto do $\mathrm{OP}$ na decisão dos executivos autárquicos relativamente aos grandes investimentos que absorvem o grosso dos recursos financeiros das autarquias.

Para além das reuniões públicas, muitas experiências têm vindo a adoptar também a utilização dos questionários de participação, seja em suporte de papel ou através da Internet. A este nível destacamos as experiências de Odivelas, que no seu primeiro ano conjugou o método digital com os debates presenciais, assim como Lisboa, que em 2008, apostou num OP de tipo de decisório exclusivamente desenvolvido através da Internet. $\mathrm{Na}$ maioria dos casos, a utilização dos suportes informáticos é porém limitada, constituindo-se sobretudo como um espaço de informação e menos como instrumentos de debate ou co-decisão, assim como acontece em muitos outros países europeus (Allegretti/Matias/Cunha, 2007).

Algumas inovações interessantes têm sido despoletadas pela experiência de Santa Leocádia do Geraz do Lima, nomeadamente a criação de um Conselho do Orçamento Participativo (COP) e de uma Caravana de Prioridades (CP). O COP é constituído por delegados eleitos em todas as comunidades da Freguesia, com poder de voto e de decisão sobre os investimentos a incluir no orçamento autárquico. A caravana $(\mathrm{CP})$ corresponde à fase do ciclo de participação que antecede a votação das prioridades, de acordo com a qual os delegados (que são porta-vozes eleitos pelos participantes) visitam localmente todas as propostas apresentadas pelos cidadãos no âmbito do OP, para que possam comparar as necessidades de cada comunidade e também reduzir o grau de ignorância que muitos habitantes tem a respeito do conjunto do território onde residem.

\section{c) Recortes organizacionais}

Em Portugal, a grande maioria dos OP está sedeada nos Gabinetes de Apoio aos Presidentes (GAP), demonstrando a aposta política que este pro- 
cesso representa. Isto significa que estas iniciativas são conduzidas técnica e politicamente por pessoas da confiança dos presidentes. Esta opção evidencia também que os processos não atingiram ainda elevados níveis de exigência dentro da administração, razão pela qual se tornam possíveis de implementar com os parcos recursos humanos dos Gabinetes de Apoio aos Presidentes. De acordo com dados recolhidos dos questionários do inquérito já mencionado, mais de $70 \%$ das experiências funcionam sem que o OP seja assumido por um pelouro ou serviço específicos. Em simultâneo, mais de 50\% dos OP's também não possui qualquer coordenação política que garanta a gestão e a avaliação dos processos.

Ao contrário, os OP's com maior nível de estruturação e complexidade, e que representam uma aposta política mais firme, tendem a gerar a necessidade interna de criação de equipas de trabalho por parte da administração. A cidade de Palmela caminhou nesse sentido depois de vários anos de experiência, tendo optado por criar uma estrutura legalmente reconhecida na orgânica geral da autarquia, responsável pela coordenação e dinamização dos diferentes processos participativos. Lisboa caminha neste momento para a criação de uma equipa de projecto que irá reunir técnicos de diferentes serviços do Município. Odivelas insere-se também nesta dinâmica, embora seja de realçar uma particularidade: o OP emerge dentro do sector financeiro da autarquia, tendo desse ponto de vista a percepção de que o OP será também um instrumento de melhoria de eficácia e eficiência financeira e orçamental do município. Outras autarquias têm vindo a criar equipas de trabalho internas, formadas essencialmente por técnicos do sector financeiro, para que sejam esses a organizar uma primeira proposta interna de modelo de $\mathrm{OP}$ a submeter à decisão política dos eleitos. Do trabalho de consultoria e formação que os autores têm desenvolvido com estas equipas é possível perceber que essas facilmente concluíram que o $\mathrm{OP}$ não poderá funcionar se o sector a que pertencem não souber mobilizar e implicar outros sectores importantes da autarquia, como por exemplo, a "acção social", a "juventude", o "associativismo", entre outras. Por esta razão os cursos de formação organizados em Lisboa na Primavera do 2009 são dirigidos também a sectores da Câmara que não seriam directamente envolvidos no trabalho de "front-office" ou de "back-office" para pôr o Orçamento Participativo 2010 a funcionar.
Outro dos aspectos que chama a atenção prende-se com a formação das equipas nas questões conceptuais e metodológicas do OP. As autarquias em que o OP é uma actividade pouco significativa e marginal tendem a não investir na formação dos seus quadros políticos e técnicos. Ao contrário, as autarquias mais preocupadas em desenhar processos com maior rigor organizacional procuram normalmente as ofertas formativas sobre o tema, assim como organizam visitas a outras experiências de OP. Os dados dos questionários recolhidos pelo projecto "Orçamento Participativo Portugal" permitem assegurar que cerca de $60 \%$ das autarquias nunca promoveu ou procurou formação para técnicos directamente envolvidos no processo; e que cerca de $90 \%$ nunca procurou assegurar essa mesma formação para funcionários que não trabalham directamente com o OP.

A este nível o Projecto "Orçamento Participativo Portugal"s tem sido determinante ao promover pela primeira vez em todo o país acções de formação, workshops e consultoria gratuita para as autarquias. Ele representou uma interessante perspectiva desde a qual ler os OP não apenas como "objectos" (dispositivos organizacionais), mas sim como elementos constitutivos de uma transformação em curso da governação territorial, do funcionamento interno das máquinas administrativas e da sua vontade de se relacionar criativamente com as novas formas da "acção colectiva".

Por fim, no que diz respeito ao enquadramento legal ou normativo dos OP, em Portugal pouco mexeu nos últimos anos. Os orçamentos participativos continuam a depender exclusivamente da vontade política dos eleitos. A criação de regulamentos ou regras dos processos acompanham um pouco a própria dinâmica de emergência deste tipo de experiências. Ou seja, os OP's de tipo decisório têm vindo a caminhar obrigatoriamente para a criação de regulamentos ou normas de enquadramento funcional do OP. É algo que resulta naturalmente das exigências dos próprios processos, da gestão da imprevisibilidade e da aprendizagem feita pelas equipas. Porém, em Portugal (diferentemente do que acontece na maioria dos OP espanhóis) nenhuma das experiências de OP possui um auto-regulamento, ou seja, um regulamento criado ou definido com a participação dos cidadãos. Em mais de $50 \%$ das experiências o OP é um processo não formalizado.

\footnotetext{
${ }^{8}$ www.op-portugal.org
} 
Apenas em Alcochete e Palmela existem comissões mistas de acompanhamento que procuram garantir o respeito das normas básicas que estruturam o processo.

Intimamente relacionada com esta matéria está a ausência de objectivos previamente definidos, assim como de processos de registo, monitorização e avaliação rigorosos, capazes de fornecer elementos que permitam aprender com as dinâmicas participativas, compreender o que corre bem e o que necessita de ser melhorado. Ao contrário do que acontece com alguns casos franceses ou brasileiros, em Portugal ainda não existem "Observatórios" independentes que façam um acompanhamento sobre os processos de $\mathrm{OP}$, incluindo a realização dos investimentos sugeridos pela população, assim como o estudo de resultados e impactos destes dispositivos participativos, como acontece em muitas cidades espanholas.

Algumas experiências, como é o caso de Odivelas, Lisboa, Sesimbra e São Brás de Alportel, os resultados do processo, nomeadamente a divulgação pública das obras e projectos aprovados no âmbito do OP é assegurada através da Internet ou de sessões públicas. No caso de Sesimbra, tem que ser assinalada uma particularidade interessante, nomeadamente $\mathrm{o}$ facto das obras aprovadas pelos cidadãos constarem da página Internet da autarquia, ilustradas com fotos e com a identificação do seu estado (lançamento, execução e conclusão).

Este tipo de detalhe sobre a prestação de contas permite pensar os processos de OP como dinâmicas com dois ciclos de participação: o primeiro dedicado ao debate e previsão orçamental e o segundo à execução das prioridades. Em ambos os momentos, os cidadãos têm um papel importante em termos de participação e vigilância democrática. Este tipo de dinâmica fomenta a aprendizagem sobre a gestão municipal e a realidade territorial, fornecendo elementos importantes para o exercício de uma cidadania e uma democracia informadas.

\section{Limites, desafios e possíveis evoluções}

Enquanto que nas primeiras experimentações (2002-2005) os OP's portugueses tinham um ca- rácter essencialmente "estável", que reproduzia de um ano a outro características organizacionais pouco evolutivas, nos últimos três anos e face à difusão numérica, à diversificação e aos contactos crescentes mantidos com experiências de outros países através de plataformas e redes internacionais como o FAL, a UCLG e o Observatório Internacional da Democracia Participativa, os processos têm-se tornado mais "evolutivos", através de uma abordagem de transformação incremental.

Seguindo a proposta da equipa internacional coordenada por Yves Sintomer ${ }^{9}$ já mencionada, os OP's em Portugal inserem-se maioritariamente na perspectiva de criação de uma democracia de proximidade (geográfica e comunicativa), sem grandes preocupações do ponto de vista da incentivação de justiça distributiva e coesão socioterritorial. Eles são primariamente considerados como instrumentos importantes no restabelecimento do diálogo entre eleitos e eleitores e na criação de uma nova fonte de legitimidade política. Apesar disto, no último período temos que registar uma mudança de paradigma que poderá no futuro ser também influenciado por modelos europeus de $\mathrm{OP}$ não mediterrâneos, como os alemães.

De facto, a participação de inúmeros técnicos dos departamentos financeiros de vários municípios em formações específicas sobre OP é um indicador interessante deste "deslizamento de centralidade". Enquanto que na Espanha e na Itália a maioria dos técnicos que são formados em OP pertencem a pelouros e departamentos de "acção social", "promoção da cidadania activa" ou - no máximo - "obras públicas", o olhar português mais recente para o OP aponta para uma nova hipótese interpretativa.

Esta denúncia que os OP's começam a ser olhados como experimentações que podem favorecer - a partir de reformas nos campos da comunicação e da coordenação interna do sector financeiro - uma nova forma de tratar as despesas e as receitas públicas. No quadro "hiper-realista" português, que tradicionalmente trabalhou com orçamentos previsionais muito desfasados da realidade das finanças públicas, os excessos de promessas (inviáveis) poderá ter contribuído para o distanciamento dos munícipes e para a perda de confiança desses nas autarquias e na política em geral. Num país que tem

\footnotetext{
9 "O panorama dos OP na Europa" in "Curso de Formação sobre Orçamentos Participativos na Europa - uma abordagem não convencional", Centro de Estudos Sociais da Universidade de Coimbra, 22 e 23 de Junho de 2007 (ver também: Allegretti/Sintomer, 2009).
} 
visto crescer a abstenção eleitoral (especialmente na área metropolitana da capital, como testemunham as últimas eleições autárquicas intercalares de Lisboa do 2006 e o Referendo sobre a Despenalização do Aborto), a necessidade de recuperar a credibilidade e a autoridade perante os cidadãos faz-se urgente e visível. Provavelmente, melhorando as relações de confiança e a "performance" na actuação administrativa poderá garantir maior eficácia nesta batalha contra a fuga no "privado" por parte dos munícipes.

Trata-se de uma mera hipótese interpretativa, mas que pode dar conta de alguns novos movimentos, nomeadamente os que advêm de algumas relações que se têm vindo a estabelecer entre Portugal e as primeiras iniciativas de $\mathrm{OP}$ no mundo escandinavo, assim como no espaço da cooperação com os PALOP. Isto demonstra a possibilidade e capacidade de articular visões e linguagens entre realidades muito distintas, eventualmente potenciadoras de novas exigências sobre os próprios processos desenvolvidos em Portugal.

O caso de Carnide, freguesia de Lisboa que através de um leque amplo de instrumentos de diálogo social (hoje chamados de "Gestão Participada", que inclui o OP mas vai além dele) pode ser um símbolo para o futuro. Aqui, neste distrito lisboeta, os dados da abstenção eleitoral são mais baixos do que as médias da cidade e do país, dando conta de como uma abordagem coerentemente dialéctica pode reconstruir laços de confiança mútua entre a cidadania e o mundo da política. Se hoje outras cidades começam a relacionar o orçamento participativo com outros instrumentos de gestão e planeamento territorial (planos de urbanismo, Agenda XXI, conselhos temáticos) pode ser que a participação nas políticas públicas tenha uma nova opção de desenvolvimento holístico.

O interesse mostrado por diferentes partidos em introduzir o OP como "motor de inovação" nos programas das eleições locais e nacionais do 2009 pode ser outro indicador de transformação a considerar.

Ficam para o futuro próximo alguns desafios ainda não enfrentados, nomeadamente a possibilidade de perspectivar o OP como "dinamizador" de uma sociedade civil ainda pouco forte e propositiva, e a oportunidade de conceber métodos de discussão e co-decisão que tornem os orçamentos participativos "motor de construção de uma solidariedade negociada" entre os cidadãos e as diferentes partes do território. Com este desafio seria óptimo voltar a reinterpretar muitas das experiências brasileiras, embora seja muito provável que algumas componentes da cultura pós-colonial (que ainda não conseguem sair de um olhar de superioridade frente aos ex-colonos) não tornem esta evolução tão próxima no tempo. De facto, nestes últimos três anos, muitas cidades portuguesas preferiram olhar para exemplos europeus de OP, com os quais se sentem culturalmente mais próximos, e tiveram a necessidade de ser suportadas por "traduções culturais" dos modelos latino-americanos que erroneamente não conseguiam olhar sozinhos como fontes credíveis de transformação institucional.

Na espera que esta abertura aos ensinamentos do Sul (Allegretti/Herzberg 2004) se torne possível também em Portugal, será útil reforçar os laços com OP's espanhóis e italianos que começam a trabalhar com empenho nesta direcção, fora de um óptica apenas de "proximidade", mas apostando em transformações administrativas e culturais mais estruturais que o OP poderá trazer, marcando um espaço importante de inovação da política como um todo, e não apenas das políticas de âmbito local.

A atenção demonstrada nos últimos três anos ao "aprender fazendo" por parte dos Orçamentos Participativos portugueses pode suportar a esperança de que o país esteja no caminho da inovação social e política, para a sair da timidez e contribuir para a transformação quanti-qualitativa do fenómeno.

Sem dúvida, o caso português demonstra - como já foi observado nos primeiros capítulos - que as inovações são fortemente marcadas pelo peso do contexto sócio-institucional e das tradições passadas, que os investigadores em economia e ciência política definem como "path-dependency". Nada faz pensar que as transferências que se multiplicam na Europa conduzirão, um dia, a uma convergência dos Orçamentos Participativos sobre um modelo único: uma síntese não parece nem possível, nem desejável (Sintomer/Allegretti, 2009). É porém razoável esperar que o recente interesse pelas potencialidades do OP em solicitar uma reorganização activa da máquina pública possa redireccionar alguns processos experimentais, reorientando-os rumo a uma "modernização participativa" (Sintomer/Herzberg/Röcke, 2005) onde a participação seja primariamente valorizada enquanto dimensão da modernização administrativa, num contexto onde 
o Estado tenta modernizar-se para obter eficácia e legitimidade, resistindo às pressões que insistem nas privatizações. Se os sindicatos alemães da função pública adoptaram a palavra de ordem "tornar-se competitivo em vez de privatizar", poderá este objectivo tornar-se actual em Portugal?

Dar uma resposta é ainda difícil. Existe, com efeito, uma afinidade electiva entre a dinâmica participativa e a modernização dos serviços públi$\cos ^{10}$ : os dois processos atraem-se mutuamente e, colocados em sintonia, são levados a transformar-se um ao outro. Os orçamentos participativos poderiam promover a introdução de novos métodos de contabilidade pública baseados na orçamentação por programas ou produtos, permitindo ao mesmo tempo que a deliberação participativa se concretize e possa levar, de maneira muito mais precisa, a melhorias que tenham efeito no funcionamento concreto das administrações. Do mesmo modo, ao nível da proximidade, as acções participativas entram em ressonância com um funcionamento mais cooperativo e mais reactivo dos serviços públicos. A outras escalas, a introdução de uma cultura de avaliação pode, com vantagem, ser vinculada ao desenvolvimento de mecanismos de feedback e de controlo dos cidadãos, enquanto a reflexão sobre a acção a longo prazo, ou sobre o desenvolvimento sustentável, dificilmente pode passar da inclusão de todas as partes envolvidas na discussão.

É verdade, porém, que na prática os resultados continuam a ser ainda modestos e que, afinal, a afinidade evocada fica ainda uma mera hipótese. Por enquanto, Portugal parece ter algumas características em comum com os modelos alemães de Orçamento Participativo, mas trata-se apenas de alguns limites que são típicos também do modelo de "democracia de proximidade": o facto de a sociedade civil beneficiar, unicamente, de uma autonomia limitada, o recurso a métodos de "consulta às finanças públicas", a qualidade da deliberação relativamente fraca e a falta de ênfase sobre o tema da justiça social. Em sentido positivo falta, porém, o verdadeiro interesse para uma concreta reorganização da máquina pública, um incentivo que ligue a eficácia do processo participativo com a estimulação pró-activa dos funcionários públicos de maneira que contribuam para uma melhor performance do processo participativo e da actuação rápida das suas prioridades, assim como o recurso ao sorteio para marcar o interesse das instituições para um maior envolvimento dos cidadãos comuns.

No entanto, a influência de Porto Alegre - embora remota em algumas práticas portuguesas de orçamento participativo - emerge como uma nota discursiva, enquanto que a referência ao New Public Management quase não entra nas reflexões políticas em torno dos OP's. Ou seja, embora existindo um interesse crescente para os "efeitos secundários" que a adopção de processos participativos centrados em temas altamente sensíveis e de forte corte técnico poderiam trazer para a modernização da máquina autárquica, em Portugal o horizonte que ilumina as experiências de $\mathrm{OP}$ diz formalmente respeito ao ideal de uma "democracia participativa»"que vai perdendo, de imediato, precisão semântica face a práticas tímidas e em evolução lenta, que muito mais se parecem a processos limitados a incidir na proximidade.

O ideal de uma democracia mais participativa constitui uma utopia realista, porque desenha um horizonte para o qual se dirige, ao mesmo tempo que designa um movimento real já iniciado, que é possível aprofundar e que parece, ao mesmo tempo, mais justo e mais eficaz do que outras tendências que marcam o presente. Mas para ele se tornar uma "orientação real" parece crucial que as experiências portuguesas façam da participação um instrumento de justiça social, de equidade entre géneros, e sejam vinculados a um movimento de afirmação das camadas subalternas conforme acontece em outros países. Um segundo desafio, mais restrito, passaria por uma melhor tomada de consciência da importância da deliberação e dos procedimentos nas dinâmicas participavas. Certamente que se verificaram progressos acentuados em relação à década anterior, mas os limites são visíveis, quando comparamos as práticas nacionais com as que estão em curso em outros países europeus ${ }^{11}$.

\footnotetext{
${ }^{10}$ A noção de afinidade electiva, utilizada por Goethe e por Max Weber em "A ética protestante e o espírito do capitalismo": a ideia é que os componentes se atraem mutuamente e, em presença um do outro, se decompõem e voltam compor-se num novo conjunto. A sua relação não é uma relação linear de causa e consequência, mas um círculo virtuoso, onde os dois elementos são, ao mesmo tempo, causa e efeito das suas transformações recíprocas.

${ }^{11}$ Sintomer/Allegretti (2009) identificam algum exemplos marcados por um quadro processual mais dinâmico. Entre eles duas experiências realizadas na Primavera de 2004 para elaborar um código de boas práticas participativas: uma organizada pela aglomeração de Grenoble, a outra pela Fundação Bofill, a Universidade Autónoma e a Diputació de Barcelona. Tanto de um lado como do outro, o objectivo não era chegar a uma versão definitiva, mas sim concretizar os diferentes artigos potenciais da Carta, definindo pontos de consenso. Em ambos os casos eram empregados métodos originais para dinamizar o debate: o jogo «2koismelthon», em Grenoble, e o sistema «Delibera», em Barcelona.
} 
Uma concepção ligeiramente mística do interesse geral - que se supõe estar automaticamente defendido pelos eleitos, "santificados pelo milagre da eleição" (Sintomer/Allegretti, 2009), ou pelos representantes de um Estado que, por natureza, seria o seu garante - desempenha, provavelmente, um papel nesta situação. Remete para uma versão de inspiração francesa do republicanismo, particularmente paternalista para com os cidadãos. E explica também, em parte, a resistência de muitos dos responsáveis políticos (especialmente no âmbito das redes e das instituições representativas nacionais das autarquias: nomeadamente ANMP e ANAFRE) em relação a dinâmicas participativas, muito superior em Portugal quando comparado com países do Norte da Europa ou com a vizinha Espanha.

De um modo mais geral, deveríamos perguntar se o obstáculo principal aos orçamentos participati- vos e às acções que associam os cidadãos à tomada de decisões substanciais de políticas públicas, não seja mesmo a sua limitação dentro do paradigma da proximidade, que coloca múltiplos problemas. Por exemplo, o carácter arbitrário da "escuta selectiva" dos habitantes ${ }^{12}$, juntamente com a ausência de garantias processuais quanto à independência da sociedade civil e à sua emancipação, risca de promover novas formas de clientelismo e de populismo. $\mathrm{O}$ paradigma da proximidade não permite a emergência de contra-poderes sociais e estimula apenas, de forma moderada, uma melhor eficácia da acção pública. Em Portugal, a participação só poderá assumir algum desenvolvimento se aproveitar todas as potencialidades dos OP's; se vencer este obstáculo de perspectiva que até hoje tem limitado a qualidade dos processos, embora permitindo a sua crescente difusão quantitativa.

\section{Bibliografia}

ABERS, Rebecca (2000), Inventing Local Democracy. Lynne Rienner Publishers, Londres.

ALLEGRETTI, G. (2005), Porto Alegre: una biografia territoriale. Ricercando la qualità urbana a partire dal patrimonio sociale, Firenze University Press, Florença.

ALLEGRETTI, G. (2003), L'insegnamento di Porto Alegre. Autoprogettualità come paradigma urbano, Alinea, Florença.

ALLEGRETTI, G. (2007), “Teorie ed esperienze di riprogettazione territoriale partecipata con gli abitanti: dal consenso alla condivisione", in M. Bertoncin; A. Pase (org.), Territorialità. Necessità di regole condivise e nuovi vissuti territoriali, Franco Angeli, Milão.

ALLEGRETTI, G. (2007b) "Territori in cammino: Democrazia partecipativa, pacificazione e accerchiamento dell 'illegalita'", in CISP

UNIVERSITA' DI PISA [org.], Osservatorio sui sistemi d'arma, la guerra e la difesa/ "Difendere, difendersi: rapporto 2005", Plus Edizioni, Pisa.

ALLEGRETTI, G., Picheral, J. B. (2002), "Il Bilancio Partecipativo in ambito europeo: tra resistenza al cambiamento e innovazione delle politiche territoriali", in P.L. Sullo [org.] (2002), Democrazia Possibile, Carta/IntraMoenia, collana "Cantieri", Napoli, pp. 327-348.

ALLEGRETTI, G.; Herzberg, C. (2004), El 'retorno de las carabelas'. Los presupuestos participativos de América Latina en el contexto europeo, TNI Working Paper/FMI, Madrid/Amsterdam/Sevilha.
ALLEGRETTI, Giovanni; Allulli, Massimo (2007), Os Orçamentos Participativos em Itália: Uma 'ponte' para a construção do Novo Município, in RCCS, n. ${ }^{\circ} 77$, Coimbra.

APPADURAI, A. (1991), "Global Ethnoscapes: Notes and Queries for a Transnational Anthropology", in R. Fox; Santa Fe, N.M [org.], Recapturing Anthropology: Working in the Present, ed. School of American Research Press, pp. 191-210.

AVRITZER, L.; Navarro, Z. (2002, org), A inovação democrática no Brasil, Cortez, São Paulo.

BACQUÈ, M.H., Rey, H., e Sintomer, Y. [dorg.] (2005), Gestion de proximité et démocratie participative. Une perspective comparative, La Découverte, Paris.

BAIOCCHI, G. (2005), Militants and Citizens, Stanford University Press.

BALEIRAS, R. N. (2004), Finanças Municipais, Seminário na Presidência da República, Faculdade de Economia/ Universidade Nova de Lisboa, 3 de Maio de 2004.

BLONDIAUX, L. e Sintomer, Y. (2002), «L’impératif délibératif», in Politix, 15.

CABANNES, Y. (2004), "Participatory budgeting: a significant contribution to participatory democracy". In: Environment \& Urbanization. Participatory Governace. Vol. $16 \mathrm{~N}^{\circ} 1$, Aprile 2004, IIED, London, pp. 27-46.

CABRAl, M. Villaverde; Carreira da Silva, Filipe; Saraiva Tiago (2008, eds.), Cidade e Cidadania. Governação Urbana e Participação Cidadã em Perspectiva Comparada, Lisboa, ICS.

\footnotetext{
${ }^{2}$ A escuta selectiva institucionaliza um diálogo regular instituições/habitantes, mas fazendo-o sobre bases processuais imprecisas, assim que as pessoas exprimem-se mas compete unicamente às instâncias representativas escolher o que pretendem integrar entre as sugestões avançadas nas discussões públicas.
} 
DIAS, N. (2006), "Em busca de uma democracia de maior proximidade", Diálogos n. ${ }^{\circ}$ 4, Rede Europeia Anti-Pobrezal Portugal.

DIAS, N. (2006a), O Orçamento Participativo como Novo Experimentalismo Democrático - o caso do Município de Guaraciaba/SC (Brasil), Dissertação de Mestrado, Lisboa, ISCTE.

DIAS, N. (2008), Orçamento Participativo - Animação Cidadã para a Participação Política, Lisboa, Associação In Loco.

DIAS, N. (2008a), "Um Tema Maior", Editorial do Boletim Informativo Orçamento Participativo Portugal n. ${ }^{\circ} 3$, Maio, Projecto OP Portugal, São Brás de Alportel.

DIAS, N. (2008b), "Uma outra democracia é possível? As experiências de Orçamento Participativo", in e-cadernos CES, 1, 183-205, Coimbra.

DIAS, N., Allegretti, G.; (2009), “The variable geometry of Participatory Budgeting: which lessons from the new Portuguese explosion?", nas Actas do Congresso "Learning Democracy by Doing: Alternative Practices in Citizenship Learning and Participatory Democracy", OISE/University of Toronto, October 18-20 do 2008.

FEDOZZI, L. (2001), Orcamento Participativo - reflexões sobre a experiência de Porto Alegre. Porto Alegre: Tomo Editorial.

GANUZA, E. (2008), Control político y participación en democracia: los presupuestos participativos, Ed. Fundación Alternativas, Madrid.

GENRO, T.; De Souza, U. (1997); Orçamento participativo. A experiência de Porto Alegre, Fundação Perseu Abramo, São Paulo.

MARQUETTI, A.; de Campos, G.; Rocha Pires, R. (2007), Democracia participativa e redistribuição: análise de experiências de orçamento participativo, Xamã, São Paulo.

MOTA, A. (2005), Governo local, participação e cidadania: o caso da Area Metropolitana de Lisboa, Lisboa, Nova Veja.

PASSERON, J. C. e Revel, J. [org.] (2005), Penser par cas, EHESS, Paris.

PLAMPER, H. (2000), Bürgerkommune: Was ist sie? Was soll sie sein? Was ist zu tun?, (Documento de trabalho 32), HansBöckler-Stiftung, Düsseldorf.
ROSANVALLON, P. (2008), La politica nell'era della sfiducia, Città Aperta, Troina.

ROSANVALLON, P. (2009), "A democracia não é só "o voto nas urnas". A subtil diferença entre "contrademocracia positiva" e "contrademocracia negativa". Entrevista a Pierre Rosanvallon, in Boletim Informativo do Orçamento Participativo Portuga", n. ${ }^{\circ} 11$, marzo 2009

SANTOS, B. de Sousa (2003, org.), Democratizar a democracia. Os caminhos da democracia participativa, Edições Afrontamento, Porto.

SANTOS, B. de Sousa (2008), "Síntese Final", in Dias, N. (Org.) Actas do I Encontro Nacional sobre Orçamento Participativo, Associação In Loco e Câmara Municipal de São Brás de Alportel, Camarate.

SINTOMER, Y.; Allegretti, G.; (2009), Os Orçamentos Participativos na Europa, Almedina, Coimbra.

SINTOMER, Y.; Herzberg, C.; Roecke, A. (2005, orgs), Participatory budgets in a European comparative approach. Perspectives and chances of the cooperative state at the municipal level in Germany and Europe - volume II (Final Report - documents), Marc Bloch Centre, Berlim.

SUBIRATS, J. (2007), "Connecting collective and individual transformation; political and economic transformation", in Networked Politics: principles and challenges, TNI, janeiro 2007.

TOURAINE, A. (1994) O que é a democracia?, Instituto Piaget, Lisboa.

UN-HABITAT (2009) 72 Perguntas frequentes sobre Orçamento Participativo, Projecto Orçamento Participativo Portugal /EQUAL, São Brás de Alportel.

WAMPLER, B. (2007), Participatory Budgeting in Brazil. Contestation, Cooperation, and Accountability, Penn State University Press.

WERNER, M. et Zimmermann, B. [org.] (2004), De la comparaison à l'histoire croisée, Le Seuil, Paris.

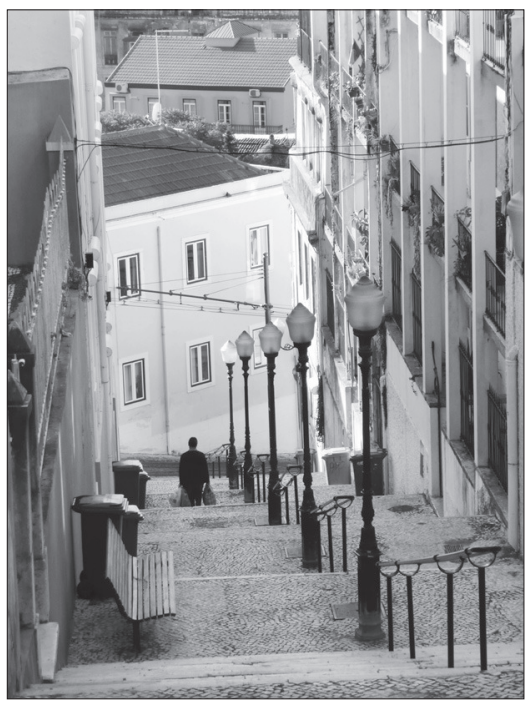

(a Pedro Corte-Real 